R. Kopach, Legal Service Officer

Air command "East", Air Force, Armed Forces of Ukraine, Dnipro, Ukraine

kopachroman@i.ua

ORCID ID 0000-0001-5892-6293,

I. Ostapenko, PhD of Judicial Sci.

Taras Shevchenko National University of Kyiv, Kyiv, Ukraine

innessa ostapenko@ukr.net

ORCID ID 0000-0003-1162-5754

\title{
LEGAL ASPECT OF PAYMENT OF THE AVERAGE AMOUNT OF CASH SUPPLY TO MILITARY SERVANTS ON THE BASIS OF A COURT DECISION
}

The article analyzes the problematic issues regarding the payment of cash benefits to servicemen in case of violation of the term of obligatory social benefits upon dismissal. It is determined that during 2018-2020 there is a practice of applying the norms of labor legislation of Ukraine to recover from the military units of the Armed Forces of Ukraine the average amount of cash during the delay of full payment of a serviceman upon discharge from military service. It is noted that this state of affairs puts excessive financial pressure on the state defense budget, and therefore it is necessary to clarify the legitimacy of the application of labor legislation to servicemen in terms of payment of the average amount of cash for the delay in discharge from military service. It is substantiated that the norms of special legislation have an exclusive advantage over the norms of labor legislation in resolving disputes concerning the full calculation of servicemen upon discharge from military service. Emphasis is placed on the fact that the practice of the European Court of Human Rights regarding the payment of average earnings to individual citizens of Ukraine during the delay in payment upon dismissal is ambiguous. It was found that at the regulatory level there is no procedure for calculating the average amount of cash collateral. It is noted that the application of the analogy of the procedure for calculating the average salary of employees is technically impossible given that the structure of monetary support of servicemen and its economic essence is different from the structure and nature of wages. It is proposed as a direction of further research to develop a compromise mechanism in the system of special legislation to strengthen the responsibility of officials of military units of the Armed Forces of Ukraine for late and incomplete payment of servicemen upon discharge from military service.

Keywords: average monthly cash security, average earnings, settlement upon dismissal, legality of payment, compensation for delay in settlement upon dismissal, norms of labor and special legislation.

УДК 342.951: 343.2/.7

DOI: https://doi.org/10.17721/1728-2217.2021.45.62-66

Д. Севост'яненко, ад'юнкт наук.-організац. від-ня Військового інституту Київський національний університет імені Тараса Шевченка, Київ, Україна sevostianenko@ukr.net

ORCID ID 0000-0001-5443-4179

\section{АСПЕКТИ ПРАВОВОГО РЕГУЛЮВАННЯ ЧОРНОГО ЕКСПОРТУ ТОВАРІВ ВІЙСЬКОВОГО ПРИЗНАЧЕННЯ ТА ПОДВІЙНОГО ВИКОРИСТАННЯ}

Здійснено науково-правове дослідження деяких аспектів правового регулювання чорного експорту товарів військового призначення та подвійного використання, а також чинного законодавства у відповідній сфері, на підставі аналізу сучасних поглядів вчених щодо визначення понять: "тіньовий ринок товарів військового призначення та подвійного використання", "чорний експорт товарів військового призначення та подвійного використання", "сірий експорт товарів військового призначення та подвійного використання". Встановлено, що процес контрабанди не є тотожним процесу чорного експорту товарів військового призначення та подвійного використання, оскільки перелік її предметів, що визначений диспозицією статті 201 Кримінального кодексу України, значно менший від досліджуваного переліку об'єктів та переліку, передбаченого Порядком здійснення державного контролю за міжнародними передачами товарів військового призначення, затвердженим Постановою Кабінету міністів України від 20 листопада 2003 р. № 1807, а також Порядком здійснення державного контролю за міжнародними передачами товарів подвійного використання, затвердженим Постановою Кабінету міністів України від 28 січня 2004 р. № 86. Наведено статті Кримінального кодексу України, за якими можуть бути кваліфіковані діяння під час здійснення досліджуваного процесу, а також запропоновано шляхи вдосконалення існуючого законодавства через внесення змін до статті 333 Кримінального кодексу України, що дозволить посилити покарання за вчинені діяння досліджуваного процесу в умовах особливого періоду та воєнного стану. Обґрунтовано необхідність подальших наукових розвідок у сфері правового регулювання тіньових ринків товарів військового призначення та подвійного використання. Варто зосередити увагу на питаннях сірого експорту, що дозволить сформувати цілісну картину щодо тіньових ринків товарів військового призначення та подвійного використання і сформувати єдину концепцію їхнього викорінення.

Ключові слова: військово-технічне співробітництво, товари військового призначення та подвійного використання, чорний експорт, контрабанда, експортний контроль.

Постановка проблеми. Однією з найважливіших факторів міжнародного миру та безпеки є унормування та обмеження імпорту та експорту товарів військового призначення та подвійного використання заради недопущення отримання зазначеної продукції міжнародними терористичними та злочинними організаціями, квазідержавними утвореннями, а також державами, що є об'єктами певних міжнародних санкцій. Проте, незважаючи на існуючі обмеження, зазначені кінцеві споживачі такої продукції знаходять шляхи ії отримання завдяки існуванню так званого чорного експорту. Зважаючи на це, а також на необхідність покращення іміджу України у світі, варто дослідити аспекти вітчизняного правового регулювання такої діяльності, а також запропонувати шляхи його вдосконалення.

Аналіз досліджень і публікацій. Дослідження ґрунтувалось на праці авторів І. Чепкова, В. Зубарєва,
В. Смірнова, А. Гупало, В. Бегми, О. Свергунова та О. Зубарєва "Військово-технічне співробітництво в системі забезпечення воєнної безпеки держави", які звернули увагу на існуючу проблему чорного експорту. Під час опрацювання статті було досліджено діюче законодавство, а також повідомлення засобів масової інформації, що дозволило сформувати уявлення про існуючу проблематику.

Мета статті полягає в теоретичному дослідженні вітчизняного правового регулювання чорного експорту товарів військового призначення та подвійного використання і формуванні пропозицій вдосконалення такого регулювання.

Виклад основного матеріалу дослідження. Геополітична структура світу першої чверті XXI ст. характеризується помірною усталеністю відносин між держа- 
вами, відносною збалансованістю сил, а також тенденцією до поглиблення взаємовигідних комунікацій між суб'єктами міжнародного права, що інтенсифікується об'єктивним процесом глобалізації. Така сучасна модель світоустрою стала можливою внаслідок визначальних подій XX ст., а саме, створення Організації Об'єднаних Націй (ООН), розпаду СРСР, Югославії та Чехословаччини, утворення Держави Ізраїль, деколонізації країн Африки та Азії, а також інших глобальних політичних процесів у багатьох регіонах Землі.

Проте, незважаючи на суб'єктивне сприйняття людиною геополітичної дійсності як загалом узвичаєної системи сьогодення, варто зауважити, що події сучасності формують постійно зростаючу тенденцію до загострення відносин між суб'єктами міжнародного права, що може призвести до деяких змін у політичному світоустрої. Наприклад, зухвала анексія Кримського півострова Російською Федерацією у 2014 р. свідчить про те, що досягнення зовнішньополітичних цілей шляхом збройного експансіонізму не сприймається сучасним вищим військово-політичним керівництвом цієї держави як анормальна поведінка суб'єкта міжнародного права, що беззаперечно призводить до зростаючої напруги у світі та підриває авторитет ООН, яка $€$ гарантом міжнародного миру та безпеки. Особливу небезпеку створює той фракт, що зазначена держава входить до так званого "Ядерного клубу", а також є постійним членом Ради Безпеки ООН, що дає їй змогу впливати на певні міжнародно-правові процеси сучасності.

Загалом зазначена подія, а також збройний конфлікт на сході України, свідчить про панування у свідомості вищого військово-політичного керівництва Російської Федерації правового нігілізму, оскільки такими міжнародноправовими актами, як Меморандум про гарантії безпеки у зв'язку з приєднанням України до Договору про нерозповсюдження ядерної зброї [1] та Статут ООН [2] на цю державу покладені обов'язки щодо убезпечення територіальної цілісності та політичної незалежності України, а також відповідальність за підтримку міжнародного миру та безпеки. Водночас заяви новообраного президента Сполучених Штатів Америки Джо Байдена щодо готовності стримувати прояви зовнішньої агресії Російської Федерації (кібератаки, втручання у внутрішньополітичні процеси інших країн, отруєння громадян тощо) $€$ логічним політичним контрзаходом на її міжнародний тиск [3].

До речі, свідченням готовності до здійснення рішучих зовнішньополітичних заходів $\epsilon$ той факт, що відповідно до заяви Джо Байдена, Сполучені Штати Америки припинять підтримку офріційного Ер-Ріяду та його союзників у здійсненні ними інтервенції у Ємен, а також призупинять продаж озброєння за укладеними зовнішньоекономічними контрактами з Саудівською Аравією [4], яка, між іншим, займає перше місце серед інших держав за обсягами імпортованого американського озброєння [5], що фактично вказує на готовність США зазнавати певних економічних збитків заради досягнення своїх цілей.

Отже, зростаюча напруга у відносинах між такими державами, як Сполучені Штати Америки, Китайська Народна Республіка та Російська Федерація, а також існування великої кількості локальних конфліктів та невирішених територіальних спорів у багатьох регіонах Землі, зобов'язує ці та інші держави підтримувати озброєння та військову техніку власних збройних сил, правоохоронних органів, а також інших військових формувань відповідно до технологічних вимог сучасності, що беззаперечно збільшить оборонний потенціал держави як організаційнополітичного формування, що несе відповідальність за безпечне існування власного населення, недоторканність кордонів та убезпечення власного суверенітету. Досягнення цієї мети для будь-якої держави уможливлюється забезпеченням зазначених потреб силами власного оборонно-промислового комплексу, а також процесами військово-технічного співробітництва.

Варто звернути увагу, що військово-технічне співробітництво, як і багато інших притаманних людству економіко-політичних процесів, унормоване міжнароднодоговірними актами та внутрішньодержавним законодавством багатьох країн, що й дозволяє імпортерам та експортерам товарів військового призначення та подвійного використання (фактично - учасникам міжнародного військово-технічного ринку) здійснювати власну зовнішньоекономічну діяльність у зазначеній сфері. Водночас законодавче регулювання означеного процесу здійснюється з метою встановлення деяких обмежень щодо розповсюдження певних товарів військового призначення та подвійного використання серед певних учасників ринку з таких причин:

- недопущення отримання означених товарів терористичними організаціями, міжнародними злочинними організаціями та державами, що є об'єктами певних міжнародних санкцій та як наслідок підтримання безпеки у певних регіонах та світі;

- регулювання розповсюдженням товарів, що можуть бути використані для виготовлення зброї масового ураження;

- збереження в таємниці деяких відомостей про досягнення за результатами науково-дослідних або дослідно-конструкторських робіт, що можуть бути використані для виготовлення або вдосконалення озброєння та військової техніки;

- дотримання заходів щодо захисту інтелектуальної власності у військово-технічній сфері;

- дотримання учасниками міжнародного військовотехнічного ринку правил торгівлі тощо.

Звичайно, існуючі обмеження, а також бажання деяких держав їх обійти, призвели до появи тіньових ринків товарів військового призначення та подвійного використання. У колективній праці "Військово-технічне співробітництво в системі забезпечення воєнної безпеки держави" за авторством І. Чепкова, В. Зубарєва, В. Смірнова, А. Гупало, В. Бегми, О. Свергунова та О. Зубарєва зазначено, що під тіньовим продажем можна розуміти сукупність чорних і сірих поставок озброєнь. Чорний експорт здійснюється переважно фрізичними особами або групою осіб, які іноді створюють з цією метою спеціальну фрірму. Організаторами чорного експорту можуть бути також суб'єкти господарювання і військові частини. Суттєвою відмінністю чорних поставок є їхня мотивація. Вони реалізуються винятково для збагачення приватних осіб. Усіляка суспільна мотивація при цьому відсутня. Фактично поняття чорного експорту і контрабанди тотожні. При виконанні чорних поставок порушується насамперед національне законодавство країни-експортера. Її міжнародні зобов'язання можуть при цьому порушуватися або ні. [6, с. 30-31]. Зважаючи на обґрунтованість такого положення варто погодитися з думкою зазначених авторів та взяти ії за основу для подальшого дослідження, проте з певними застереженнями. Зокрема, автори зазначають, що об'єктом тіньового (відповідно і чорного) експорту є саме озброєння, а також вказують на те, що чорний експорт і контрабанда є ідентичними процесами, хоча, на нашу думку, ототожнювати їх не варто, 
оскільки частиною першою статті 201 Кримінального кодексу України встановлюється, що контрабандою є переміщення через митний кордон України поза митним контролем або з приховуванням від митного контролю культурних цінностей, отруйних, сильнодіючих, вибухових речовин, радіоактивних матеріалів, зброї або боєприпасів (окрім гладкоствольної мисливської зброї або бойових припасів до неї), частин вогнепальної нарізної зброї, а також спеціальних технічних засобів негласного отримання інформації [7]. Фактично зазначена норма встановлює дефініцію поняттю "контрабанда", а також встановлює вичерпний перелік ії̈ предметів. Водночас Законом України "Про державний контроль за міжнародними передачами товарів військового призначення та подвійного використання" встановлено, що міжнародними передачами товарів є, у тому числі, імпорт та експорт товарів військового призначення та подвійного використання [8], які фактично є одними з об'єктів військово-технічного співробітництва та відповідно об'єктами притаманних йому деструктивних процесів (чорний і сірий експорт).

Відповідно до норм зазначеного вище Закону України передбачено, що товарами військового призначення в сукупності чи окремо є вироби військового призначення (озброєння, боєприпаси, військова та спеціальна техніка, спеціальні комплектуючі вироби для їхнього виробництва, вибухові речовини, а також матеріали та обладнання, спеціально призначені для розроблення, виробництва або використання зазначених виробів), а також технології військового призначення. А товарами подвійного використання $є$ окремі види виробів, обладнання, матеріалів, програмного забезпечення і технологій, спеціально не призначені для військового використання, а також послуги (технічна допомога), пов'язані з ними, які, окрім цивільного призначення, можуть бути використані у військових або терористичних цілях чи для розроблення, виробництва, використання товарів військового призначення, зброї масового знищення, засобів доставки зазначеної зброї чи ядерних вибухових пристроїв, у тому числі, окремі види ядерних матеріалів, хімічних речовин, бактеріологічних, біологічних та токсичних препаратів.

Зважаючи на вищевикладене, доходимо висновку, що об'єктом чорного експорту може бути не тільки озброєння, яке належить до товарів військового призначення, а й інші такі товари та товари подвійного використання, перелік яких значно більший, аніж перелік предметів контрабанди, передбачений Кримінальним кодексом України. Тим паче, що такі злочини доволі поширені в Україні $[9,10]$, а їхня диспозиція, у разі, якщо об'єктом чорного експорту не є предмети контрабанди, передбачена статтею 333 Кримінального кодексу України, санкція якої передбачає відповідальність за порушення порядку здійснення міжнародних передач товарів, що підлягають експортному контролю.

Окрім вищевказаного, варто зауважити, що, як вже було зазначено, серед товарів військового призначення та подвійного використання окремою категорією виділені технології, які також можуть бути об'єктом чорного експорту. Звід відомостей, що становлять держану таємницю, затверджений Наказом Центрального управління Служби безпеки України від 23 грудня 2020 року № 383, передбачає перелік відомостей про технології військового призначення та подвійного використання, які становлять державну таємницю, а саме:

- відомості про нові технології створення (модернізації) зразків озброєння (військової техніки) для пот- реб оборони, що спрямовані на поліпшення їхніх бойових можливостей або конструктивних (експлуатаційних) характеристик;

- відомості про рецептуру або технологію виробництва матеріалів військового призначення;

- відомості за окремими показниками про повний рецептурний склад, особливості технології виготовлення піроксилінових (балістичних, сферичних чи інших) порохів (боєприпасів), що виготовляються для військового озброєння;

- відомості про технології подвійного призначення, що мають перевагу порівняно з кращими зарубіжними аналогами, якщо вони дають змогу відтворення цих технологій або розкривають їхні характеристики за призначенням;

- відомості за сукупністю всіх показників про виробничі потужності, обсяги, технологію виробництва матеріалів, які передбачено використовувати для виготовлення озброєння (боєприпасів, військової техніки, спеціальних комплектувальних виробів до них);

- відомості за окремими показниками про результати наукових, науково-дослідних (дослідно-конструкторських) та проєктних робіт у галузі дослідження (використання) космічного простору, на базі яких можуть бути створені прогресивні технології, нові види виробництва, продукції та технологічних процесів, що мають важливе оборонне чи економічне значення або суттєво впливають на зовнішньоекономічну діяльність та національну безпеку України;

- відомості за окремими показниками про результати наукових, науково-дослідних, дослідно-конструкторських, проєктних робіт зі створення високоенергетичних матеріалів, зарядів, боєприпасів, ракетних двигунів на основі твердого ракетного палива, створення технологій та потужностей у галузі виробництва та утилізації ракетної техніки, її складових частин, високоенергетичних матеріалів та виробів, боєприпасів, витік яких створює загрозу національним інтересам і безпеці;

- відомості за окремими показниками про результати наукових, науково-дослідних (дослідно-конструкторських) або проєктних робіт у галузі створення чи забезпечення функціонування в умовах завад апаратури користувачів супутникових систем координатно-часового та навігаційного забезпечення, на базі яких можуть бути створені нові види продукції чи прогресивні технології, що мають важливе оборонне чи економічне значення або суттєво впливають на зовнішньоекономічну діяльність та національну безпеку України;

- відомості за окремими показниками про наукові відкриття, зовнішній вигляд, винаходи, зміст, результати науково-дослідних (дослідно-конструкторських) робіт, тактико-технічні характеристики, організацію, технологію розробки (виробництва), модернізацію спеціальних технічних засобів (зброї), що розкривають організацію, методику, тактику їх негласного застосування під час вирішення завдань оперативно-розшукової, контррозвідувальної чи розвідувальної діяльності, володіння якими дає змогу зацікавленій стороні впливати на їхні результати, що створює загрозу національним інтересам і безпеці [11].

Отже, дії осіб, які здійснили несанкціоновану транскордонну передачу вищевказаних технологій, що передбачені Списком товарів військового-призначення, міжнародні передачі яких підлягають державному контролю, що встановлений Порядком здійснення державного контролю за міжнародними передачами товарів військового 
призначення, затвердженим Постановою Кабінету міністрів України від 20 листопада 2003 р. № 1807 [12], а також технологій, які передбачені Єдиними списком товарів подвійного використання, що встановлений Порядком здійснення державного контролю за міжнародними передачами товарів подвійного використання, затвердженим Постановою Кабінету міністрів України від 28 січня 2004 р. № 86 [13], мають бути кваліфріковані відповідно до статті 33 Кримінального кодексу України. Тобто, окрім статті 333 Кримінального кодексу України, суб'єкту злочину необхідно інкриміновувати кримінальне правопорушення, передбачене статтею 328 Кримінального кодексу України, санкція якої передбачає відповідальність за розголошення відомостей, що становлять державну таємницю, особою, якій ці відомості були довірені або стали відомі у зв'язку з виконанням службових обов'язків.

Також залежно від статусу суб'єкта кримінального правопорушення, його дії можуть бути кваліфіковані за статтею 422 Кримінального кодексу України (у разі, якщо суб'єкт є військовослужбовцем або військовозобов'язаним під час проходження зборів); статтею 111 Кримінального кодексу України (у разі, якщо суб'єкт є громадянином України, що досяг 16 років і якому відомості, що становлять державну таємницю стали відомі не у зв'язку з виконанням ним службових обов'язків), а також статтею 114 Кримінального кодексу України (у разі, якщо суб'єкт є іноземцем або особою без громадянства).

Підсумовуючи, зауважимо, що за інформацією засобів масової інформації [14] у 2018 р. співробітники Служби безпеки України викрили зловмисників, які здійснювали експорт окремих товарів військового призначення та подвійного використання до Російської Федерації, які використовувалися для виготовлення озброєння та військової техніки, що в подальшому передавалися незаконним збройним формуванням, які діють на території України, тимчасово окупованої внаслідок збройної агресії Російської Федерації. Фактично такі дії чорних експортерів завдають шкоди державній безпеці України, проте вони не можуть бути кваліфріковані за статтею 111 Кримінального кодексу України, адже диспозиція цією статті передбачає саме умисне діяння, вчинене громадянином України, проте фракт виготовлення озброєння та військової техніки з експортованих товарів на території Російської Федерації, а також факт подальшої їхньої передачі незаконним збройним фрормуванням, суб'єктам злочину міг бути невідомий, що виключає кваліфрікацію їхніх дій як надання іноземній державі, іноземній організації або їхнім представникам допомоги в проведенні підривної діяльності проти України.

Зважаючи на цей випадок, а також припускаючи, що він непоодинокий, вважаємо необхідним доповнити статтю 333 Кримінального кодексу України частиною третьою, санкція якої буде передбачати кримінальну відповідальність у вигляді позбавлення волі за порушення порядку здійснення міжнародних передач товарів, що підлягають державному експортному контролю в умовах особливого періоду, окрім воєнного стану, а також частиною четвертою, санкція якої буде передбачати кримінальну відповідальність у вигляді позбавлення волі за порушення порядку здійснення міжнародних передач товарів, що підлягають державному експортному контролю в умовах воєнного стану.

Висновки. У результаті вивчення наукових праць 3 метою формування уявлення про тіньовий ринок товарів військового призначення та подвійного використання, та керуючись особливими принципами його диференціації на чорний і сірий експорт, проведено теоретичне дослідження аспектів правового регулювання чорного експорту товарів військового призначення та подвійного використання в Україні. У результаті аналізу статтей Особливої частини Кримінального кодексу України, які кваліфрікують діяння, що мають ознаки чорного експорту, запропоновано внести зміни до чинного законодавства 3 метою посилення покарання за вчинення вказаних кримінальних правопорушень.

\section{Список використаної літератури}

1. Меморандум про гарантії безпеки у зв'язку з приєднанням України до Договору про нерозповсюдження ядерної зброї : Міжнар. док. від 05.12.1994. URL: https://zakon.rada.gov.ua/laws/show/998_158\#Text (дата звернення: 17.02.2021)

2. Статут Організації Об'єднаних Націй і Статут Міжнародного Суду : Міжнар. док. від 26.06.1945. Дата оновлення: 16.09.2005. URL: https://zakon.rada.gov.ua/laws/show/995_010 (дата звернення: 17.02.2021).

3. Байден: Дні, коли США відступали перед агресією Росії, минули. URL: https://www.bbc.com/ukrainian/news-55946359 (дата звернення: 18.02.2021).

4. Байден: "Эту войну нужно остановить!". URL: https://www.golosameriki.com/a/world-us-yemen/5767029.html (дата звернення: 18.02.2021).

5. Saudi Arabia buys the most weapons from the US government. See what other countries top list. URL: https://www.usatoday.com/story/ money/2019/03/26/us-arms-sales-these-countries-buy-most-weaponsgovernment/39208809/ (дата звернення: 18.02.2021).

6. Теорія озброєння. Науково-технічні проблеми та завдання : монографія. Т. 2. Військово-технічне співробітництво в системі забезпечення воєнної безпеки держави / І. Б. Чепков, В.В.Зубарєв, В. О. Смірнов та ін. - Київ : Вид. дім Дмитра Бураго, 2015. - 404 с.

7. Кримінальний кодекс України: Закон України від 05.04.2001 p. № 2341-III. // Відомості Верховної Ради України, 2001. - № 25-26. Ст.131. URL: https://zakon.rada.gov.ua/laws/show/2341-14\#Теxt (дата 23.02.2021).

8. Про державний контроль за міжнародними передачами товарів військового призначення та подвійного використання : Закон України від 20.02.2003. № 549-IV. Дата оновлення: 24.10.2020. URL: https://zakon.rada.gov.ua/laws/show/549-15\#Техt (дата звернення: 23.02.2021).

9 СБУ припинила вивіз товарів військового призначення з України. URL: https://ua.korrespondent.net/ukraine/4115821-sbu-prypynyla-vyviz-tovarivviiskovoho-pryznachennia-z-ukrainy (дата звернення: 23.02.2021).

10. У киянина вилучили деталі для систем ППО. URL: https://ua.korrespondent.net/ukraine/4204931-u-kyianyna-vyluchyly-detalidlia-system-рро (дата звернення 24.02.2021).

11. Звід відомостей, що становлять державну таємницю : затв. наказом Центрального управпіння Служби безпеки України від 23.12.2020. № 383. URL: https://zakon.rada.gov.ua/laws/show/z0052-21\#n7 (дата звернення: 25.02.2021).

12. Порядок здійснення державного контролю за міжнародними передачами товарів військового призначення : затв. постановою Кабінету Міністрів України від 20.11.2003. № 1807. URL: https://zakon.rada.gov.ua/ laws/show/1807-2003-\%D0\%BF\#Text (дата звернення: 24.02.2021).

13. Порядок здійснення державного контролю за міжнародними передачами товарів подвійного використання : затв. постановою Кабінету Міністрів України від 28.01.2004. № 86. URL: https://zakon.rada.gov.ua/ laws/show/86-2004-\%D0\%BF\#Text (дата звернення: 24.02.2021).

14. СБУ перекрила канал постачання комплектувальних військової техніки. URL: https://ua.korrespondent.net/ukraine/4013955-sbu-perekrylakanal-postachannia-komplektuvalnykh-viiskovoi-tekhniky (дата звернення: 25.02.2021).

\section{References}

1. Memorandum on Security Assurances in connection with Ukraine's accession to the Treaty on the Non-Proliferation of Nuclear Weapons (1994, December 05) URL: https://zakon.rada.gov.ua/laws/show/998 158\#Text [in Ukrainian].

2. The Charter of the United Nations (1945, June 26) URL: https://zakon.rada.gov.ua/laws/show/995 010 [in Ukrainian].

3. Biden: Gone are the days when the United States retreated before Russia's aggression. URL: https://www.bbc.com/ukrainian/news-55946359 [in Ukrainian].

4. Biden: "This war must be stopped!". URL: https://www.golosameriki.com/ a/world-us-yemen/5767029.html [in Ukrainian].

5. Saudi Arabia buys the most weapons from the US government. See what other countries top list. URL: https://www.usatoday.com/story/ money/2019/03/26/us-arms-sales-these-countries-buy-most-weaponsgovernment/39208809/

6. Chepkov, I. B., Zubariev, V. V., \& Smirnov, V. O. et al. (2015). Weapon theory. Scientific and technical problems and tasks: monograph: V. 2. Military-technical cooperation in the system of ensuring the military security of the state. KYIV: Dmytro Buraho publishing house [in Ukrainian]. 
7. Criminal Code of Ukraine (2001, April 05) Vidomosti Verkhovnoi Rady Ukrainy. URL: https://zakon.rada.gov.ua/laws/show/2341-14\#Text [in Ukrainian].

8. Law of Ukraine about state control over international transfers of military and dual-use goods № 549-IV (2003, February 20). Vidomosti Verkhovnoi Rady Ukrainy. URL: https://zakon.rada.gov.ua/laws/show/54915\#Text [in Ukrainian].

9 SSU stopped the export of military goods from Ukraine. URL: https://ua.korrespondent.net/ukraine/4115821-sbu-prypynyla-vyviz-tovarivviiskovoho-pryznachennia-z-ukrainy [in Ukrainian].

10. Details for the air defense system were confiscated from a Kyivan. URL: https://ua.korrespondent.net/ukraine/4204931-u-kyianyna-vyluchylydetali-dlia-system-ppo [in Ukrainian]

11 Code of information constituting a state secret: Decree of the SSU № 383 (2020, December 23). URL: https://zakon.rada.gov.ua/laws/show/z005221\#n7 [in Ukrainian].

\section{Sevostianenko, Postgraduate Stud.}

Scientific and Organizational Department of the Military Institute Taras Shevchenko National University of Kyiv, Kyiv, Ukraine sevostianenko@ukr.net

ORCID ID 0000-0001-5443-4179

\section{ASPECTS OF LEGAL REGULATION OF MILITARY AND DUAL-USE GOODS BLACK EXPORT}

The research on some aspects of legal regulation of military and dual-use goods black exports is carried out in the article. It is based on the analysis of modern views of scientists on the definition of "shadow market of military and dual-use goods", "black export of military and dual-use goods", "gray export of military and dual-use goods", as well as current legislation in relevant field. It is established that the smuggling process is not identical to the process of black export of military and dual-use goods, as the list of its items, as defined by Article 201 of the Criminal Code of Ukraine, is much smaller than the list of objects within the process investigated in the article and the inventory of which is stipulated by the state control over international transfers of military goods, approved by the Resolution of the Cabinet of Ministers of Ukraine of November 20,2003 No 1807, as well as the Procedure for state control over international transfers of dual-use goods approved by the Cabinet of Ministers of Ukraine of January 28, 2004 № 86. The articles of the Criminal Code of Ukraine according to which actions within the process under consideration can be qualified are given, as well as the ways of improvement of the existing legislation, through modification of article 333 of the Criminal code of Ukraine that will allow to strengthen punishments for the made actions of the investigated process in the conditions of the special period state. The need for further research in the field of legal regulation of shadow markets for military and dual-use goods should be focused on gray exports, which will form a holistic picture of shadow markets for military and dual-use goods and form a single concept of their eradication.

Keywords: military-technical cooperation, military and dual-use goods, black export, smuggling, export control. 